\title{
Effect of Neuro Dynamic Mobilization on Pain and Hand Grip Strength in Cervical Radiculopathy Patients
}

\author{
HEBA MOHAMMED, M.Sc.*; ENAS ELSAYED, Ph.D.*; YOUSSEF ELBALAWY, Ph.D.* and \\ AZZA GHALLY, Ph.D.** \\ The Department of Physical Therapy for Neuromuscular Disorders and its Surgery, Faculty of Physical Therapy, \\ Cairo University* and The Department of Neuropsychiatry, Faculty of Medicine, Tanta University**, Egypt
}

\begin{abstract}
Background: Cervical Radiculopathy (CR) is a pathological condition of the cervical roots, which results in sensory and motor deficits. There is evidence supporting the influence of neural mobilization in relieving CR symptoms.

Aim of Study: The aim of the study was to evaluate the effect of neuro dynamic mobilization on hand grip strength and pain in patients with chronic cervical radiculopathy.

Methods: Thirty participants with cervical pain radiating to the upper limb were recruited from the Outpatient Departments of El-Menshawy General Hospital from 16-11-2019 till 4-4-2019, their age ranged between 30-50 years. Patients were divided into three equal groups Group (1) received neural mobilization for ulnar, median, and radial nerves in addition to selected physical therapy program. Group (2) received neural mobilization for ulnar and median nerves in addition to the selected physical therapy program while Group (3) received only the selected physical therapy program for four weeks. Assessment of pain using visual analogue scale (VAS) and hand grip using jamar hand-held dynamometer were done before and after treatment.

Results: The findings revealed a statistically significant decrease of pain scores within each group and increase in hand grip strength within each group post-treatment $(p<0.05)$. Also, there was no a statistically significant difference in handgrip strength between the affected and unaffected sides after treatment in Group (1) which received median, ulnar, and radial nerves neurodynamic mobilization $(p<0.05)$. On the opposite side, the results showed a statistically nonsignificant difference between the three groups regarding pain and hand grip strength after treatment $(p>0.05)$.
\end{abstract}

Conclusion: Addition of radial nerve mobilization to ulnar and median neuro dynamic mobilization technique is effective in improving symptoms of chronic CR.

Key Words: Cervical radiculopathy - Neuro dynamic mobilization-Grip strength - Visual analogue scale.

Correspondence to: Dr. Heba Mohammed, The Department of Physical Therapy for Neuromuscular Disorders and its Surgery, Faculty of Physical Therapy, Cairo University, Egypt

\section{Introduction}

CERVICAL radiculopathy is the clinical description of when a nerve root in the cervical region becomes inflamed or damaged, leading to a change in neurological function. Neurological deficits like numbness, muscle weakness and potential loss of movement [1]. This condition is commonly caused by cervical disc herniation or growing osteophytes from the posterior vertebral bodies. Nerve roots of the lower cervical spine are mostly affected [2]

Patients with CR often present symptoms of muscle weakness. According to the kinetic chain principles, the upper limb is a system of linked segments working together to perform daily activities. In other words, muscle weakness produced in one segment of the affected upper limb would contribute to a generalized muscle weakness and consequently reduced grip strength [3]

Maintenance of grip strength of the upper extremity is essential for various functional activities in daily life [4]. However, the integrity of the nervous tissue is required to be well intact to attain a maximum outcome of grip strength $[\mathbf{5 , 6 ]}$. That is to say; its physical and physiological properties need to function at an optimum level. Since weakness of grip strength is often presented in patients with $\mathrm{CR}$, it becomes a necessity to implement an effective treatment technique to restore its strength [3,7].

Neural mobilization plays an important role in restoring movement and elasticity of the nervous system, promoting return to normal functions $[8,9]$. The technique involves movement and/or tension of the nervous system, which results in reduced intrinsic pressure of the neural tissue and can reestablish the neural biomechanics such as elasticity 
and axoplasmatic flow, to tolerate normal compressive, tensile and friction forces associated with daily and sport activities [7,10]

In addition, neural mobilization allows for an improvement in the motor unit recruitment, thereby improving muscle strength. Also, mobilization of the nervous system has long been known to reduce pain intensity and improve related symptoms in neural disorders $[\mathbf{5 , 7 , 1 1}]$.

Ragonese [12] carried out a randomized trial comparing manual therapy (cervical lateral glides, nerve glides, and thoracic mobilizations) against therapeutic exercises for neck muscles or a combination of both. The group which received the combination of exercise and manual therapy demonstrated the greatest improvements in terms of pain and disability after nine treatment sessions. Also, Nee [13] reported that neural mobilization has immediate, clinically relevant benefits in patients with related neck and arm pain after only four treatment sessions without any adverse effects.

\section{Aim of the study:}

The aim of the study was to investigate the effect of neuro dynamic mobilization on pain and hand grip strength in CR patients.

Specific aim: The current study also aimed to investigate the effect of adding radial nerve to ulnar and median mobilization techniques on pain and grip strength in patients with chronic CR.

\section{Subjects, Material and Methods}

\section{Subjects:}

Thirty patients were recruited from the Outpatient Departments of El-Menshawy General Hospital (27 females and 3 males), in the age group of 30 to 50 years. They were diagnosed with CR by their respective orthopedic or neurological consultants and referred for physical therapy management.

\section{Inclusion criteria:}

1- Cervical pain radiating to the upper limb (below deltoid tuberosity).

2- Chronic stage (6-18 month).

3- A decreased grip strength.

4- A positive Upper Limb Neural Tension (ULNT) test and spurling's compression test.

5- Sensory changes in dermatome distribution [18]

\section{Exclusion criteria:}

Any pathology preventing neural tissue testing (eg: Restriction of joint range of motion), cervical myelopathy, fracture, instability, history of previous cervical surgery, gross neurological deficits, thoracic outlet syndrome, inflammatory arthritis, medical red flags (dizziness caused by vertebrobasilar insufficiency) and severe psychiatric disorder or cognitive deficits.

Patients were divided randomly into three equal groups: Group (1) received neural mobilization for ulnar, median, and radial nerves in addition to a selected physical therapy program. Group (2) received neural mobilization for ulnar and median nerves in addition to the selective physical therapy program. Group (3) received only the selected physical therapy program.

\section{Material:}

- Jamar Hand dynamometer S.N30107301 was used to measure hand-grip strength. The dynamometer has been confirmed to be a valid tool for determining grip strength and has excellent test-retest reliability [14]

-Visual analogue scale ranged from 0-10 was used to determine the patient's perceived level of pain.

\section{Methods:}

Study design: Pre test-post test randomized controlled trial.

A consent form was obtained from patients after comprehensive explanation of the aim and procedures of the study. The study proposal was approved by the Research Ethical Committee of the Faculty of Physical Therapy, Cairo University.

Pain assessment procedure: Visual analogue scale is widely used to investigate many kinds of subjective experience, including pain [15]. The scale has also been applied to alertness after sleep, quality of life, anxiety, breathlessness, nausea, and attitudes towards the environment [16,17] .

Patients were asked to indicate intensity by marking a $100-\mathrm{mm}$-long horizontal line that is labeled "no pain" at one end and "worst pain possible" at the other end. This requireed the patient to be able to equate the length of the line (as measured from the left-hand side to the point marked) with the amount of pain they are experiencing. There is evidence to support the construct validity of VAS. The scales correlate with pain intensity measured by other methods $[18,19]$ they are considered to be sensitive to interventions that alter the pain experience [20]

Hand grip assessment procedure: The patient was asked to sit on a straight back chair with his/her 
feet flat on the floor. The affected shoulder was to be maintained at $0^{\circ}$ of flexion, abduction and rotation, elbow flexed to $90^{\circ}$, forearm rested in a neutral position with the wrist in minimal extension and ulnar deviation. On achieving the standardized arm position, the dynamometer set at the second handle space was given to subjects who were then advised to perform 3 maximum gripping efforts for 5 seconds. A 15 second rest period was given to prevent fatigue effects. While performing each trial, each patient was instructed by the assessor as follows: "Squeeze the handle as hard as possible". The mean value of the 3 efforts (measured in pounds) was evaluated for the analysis of grip strength. The patients were not allowed to see their score in each trial. No visual and verbal encouragement was given for achieving the maximum capable grip strength.

Treatment procedures: Neural gliding techniques were applied for four weeks (12 sessions), 10 repetitions were given for each nerve. The selective physical therapy program included 10 minute hot packs on the cervical and upper back, five minutes ultrasound for neck, 20 minute Transcutaneous Electrical Nerve Stimulation (TENS) [21], stretching and strengthening exercises for the cervical and shoulder muscles [22]. In addition, to intermittent cervical spine traction was applied [23].

\section{Neuro dynamic mobilization technique:}

Startingposition: For the right side, the patient was asked to lie on the right side of the treatment bed with the scapula free. The legs and trunk are angled to the left of the bed so that the patient feels relaxed and supported. A pillow was placed under the head if required. The researcher's left thigh was rested against the patient's right shoulder and her hands supported the patient's arm at the elbow and wrist joints. The following movements were performed passively by the therapist:

Median nerve: Shoulder girdle depression, abduction to 110, elbow extension, forearm supination and wrist and finger extension. Contralateral side cervical bending was added for further sensitization.

Radial nerve: Shoulder girdle depression, abduction to 10 , shoulder medial rotation, elbow extension, forearm pronation, wrist flexion, ulnar deviation, finger and thumb flexion, and contralateral side bending of cervical spine.

Ulnarnerve: Shoulder girdle depression, shoulder lateral rotation and abduction (10-90), elbow flexion, forearm supination, wrist extension and radial deviation with fingers and thumb extension, and contralateral side cervical bending.

\section{Data analysis:}

The statistical analysis was conducted by using statistical SPSS Package program Version 20 for Windows (SPSS, Inc., Chicago, IL). Descriptive statistics including the mean and standard deviations for age was used. ANOVA test was used for comparison between the three groups. Student $t$ test was used to compare within groups. Significant level was at 0.05 level of probability $(p \leq 0.05)$.

\section{Results}

\section{General characteristics of the patients:}

The mean age of the patients was $39.53 \pm 7.43$ years. There was no significant difference between the three groups regarding age $(p=.58)$. The study sample included $90 \%$ females and $10 \%$ males. The causes of CR were spondylosis $(23.3 \%)$ and disc prolapse $(76.7 \%)$.

\section{Pain:}

The results showed non-significant difference between Groups A, B, and C regarding mean values of VAS scores both before treatment $(p=.71)$ and after treatment $(p=.32)$. On the contrary, a highly significant decrease in VAS mean values was found after treatment compared to that before treatment in each group ( $p^{<.0001)}$ (Table 1) and Fig. (1).

Table (1): Comparison of the three groups regarding VAS score mean values before and after treatment

\begin{tabular}{llllc}
\hline VAS & Group (1) & Group (2) & Group (3) & $p$ \\
\hline Pre & $8.2 \pm 1.14$ & $8.5 \pm 1.18$ & $8.1 \pm .99$ & $.58(\mathrm{NS})$ \\
Post & $2.9 \pm 1.45$ & $3.6 \pm 1.71$ & $3.8 \pm .79$ & $.32(\mathrm{NS})$ \\
$p$ & $.0001^{*}$ & $.0001^{*}$ & $.0001^{*}$ & \\
\hline
\end{tabular}

NS: Non significant

* : Highly significant.

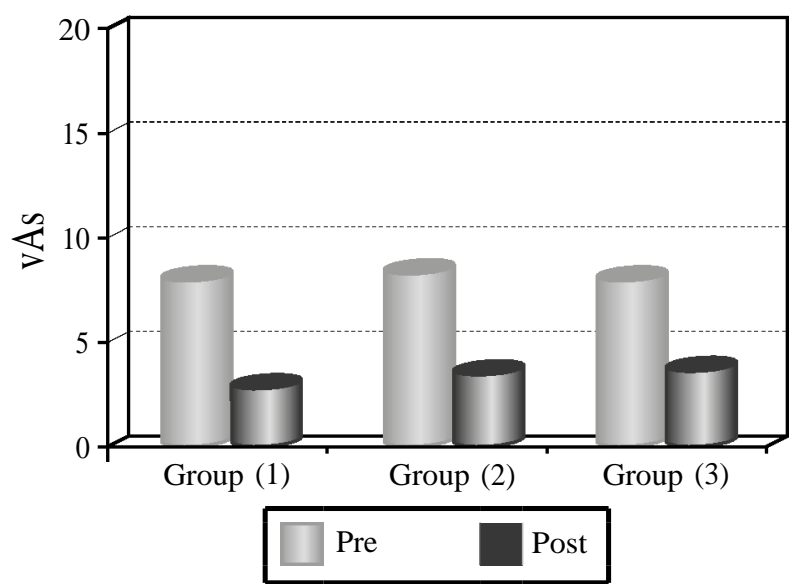

Fig. (1): Mean values of VAS scores in the three study groups before and after treatment. 


\section{Hand grip strength:}

The results showed non-significant difference between Groups (1), (2), and (3) regarding mean values of hand grip strength of the affected limb both before treatment ( $p=.24)$ and after treatment $(p=.82)$. On the other hand, a significant increase in the grip strength mean values was revealed after treatment compared to that before treatment within each group $(p<.05)$ (Table 2) and Fig. (2).

The findings also showed that there was significant difference between affected and unaffected sides regarding hand grip strength both before and after treatment in Groups (2) and (3) $(p<.05)$. On the other hand, group (1) showed no significant difference after treatment between affected and unaffected side $(p>.05)$ compared to that before treatment $(p=.05)$.

Table (2): Comparison of the three groups regarding hand grip strength mean values before and after treatment.

\begin{tabular}{llllc}
\hline $\begin{array}{l}\text { Hang Grip } \\
\text { Strength } \\
(\mathrm{Kg})\end{array}$ & Group (1) & Group (2) & Group (3) & $p$ \\
\hline Pre & $13.4 \pm 4.09$ & $11.01 \pm 6.82$ & $15.26 \pm 5.25$ & $.58(\mathrm{NS})$ \\
Post & $18.65 \pm 3.61$ & $17.05 \pm 7.6$ & $18.11 \pm 5.38$ & $.32(\mathrm{NS})$ \\
$p$ & $.000^{*}$ & $.007 *$ & $.02 *$ & \\
\hline
\end{tabular}

NS: Non significant.

* : Significant

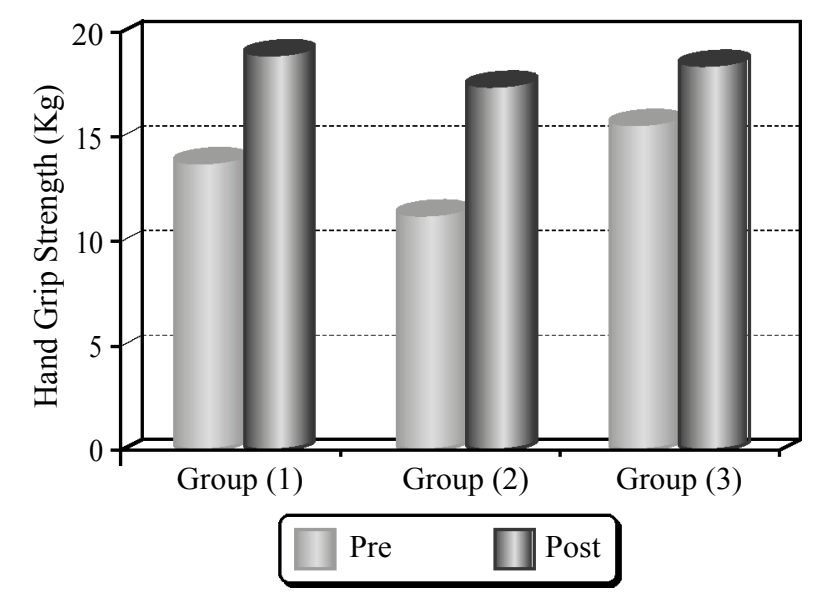

Fig. (2): Mean values of hand grip strength in the three study groups before and after treatment.

\section{Discussion}

Despite positive effects of neural mobilization in clinical practice, few studies have demonstrated its effect on grip strength. One such study done by Tejashree and Ajit [24] gave an insight on the effects of neural mobility on functioning of neural mobility. The authors had verified positive benefits of neural mobilizations on pinch and grip strength in healthy individuals which could thus be applicable for treatment of various pathologies. In view of this, the present study was performed on patients with $\mathrm{CR}$, with an aim to find out the effects of neural mobilization on grip strength and pain and the importance of radial nerve mobilization in addition to median and ulnar nerves for grip strength and pain relief. The positive results of the current study revealed significant increase on hand grip after treatment compared to that before treatment in the Group (1) and significant decrease in VAS scores after treatment compared to that before treatment in all groups.

This came in agreement with Ellis and Wa [25] who studied neural mobilization, a systematic review of randomized controlled trials with an analysis of therapeutic efficacy and concluded a positive therapeutic benefit from using neural mobilization. In addition, the significant increase in hand grip strength after neural mobilization came also in agreement with Coppieters [26] who studied the immediate effects of a cervical lateral glide treatment technique in patients with neurogenic cervico-brachial pain. They concluded that neural mobilization increased elbow extension, decreased the area of symptom distribution and pain intensity.

Moreover, the significant improvement in hand grip strength in Group (1) came in accordance with the results obtained from a randomized experimental study done by Sambyal and Kumar [27]. They compared the effectiveness of nerve mobilization treatment on pain compared to conventional physiotherapy. They reported that both interventions were effective therapeutic options in the treatment of CR but nerve mobilization was more beneficial in improving pain.

In the same line, Ranade and Snehal [28] conducted a study on the effect of neural tissue mobilization on cylindrical grip strength in old adults. The results showed a significant difference in the means of grip strength before and after mobilization in males and females (males improved more than female) which come in agreement with the findings of current work.

The positive results revealed by neural mobilization could be attributed to its ability to cause a cascading change in its physiological function. The stretch applied to the nerve triggers an increase in acting polymerisation, force generation, release of neurotransmitters and intra-neural circulation. This results in better recruitment of motor units and consequent increase in handgrip strength. 
Cleland mentioned that when the nerve root was compressed and microcirculation was compromised; and the pressure received by the nerve will affect the edema and the demyelination, neurodynamic techniques consists of short oscillatory movements and was sufficient to disperse the edema, thus alleviating the hypoxia and reducing the associated symptoms. It could also be directly associated with the immobilization reduction in the neurogenic inflammation. In addition, there is the hypothesis that nerve movement within painfree variations can help to reduce nerve compression, friction and tension, therefore decreasing its mechanosensitivity [29] (Cleland J et al., 2006).

The findings of the present study were contradicted with the those of Nair [30] who investigated the immediate effect of neural tissue mobilization on grip strength in patients with $\mathrm{CR}$. He reported no positive results obtaind. This contradiction might be due to that only median and ulnar nerves neuro dynamic mobilization was applied without radial nerve.

\section{Conclusion:}

Addition of radial nerve mobilization to ulnar and median neuro dynamic mobilization technique is effective in improving symptoms of chronic CR.

\section{References}

1- ROD INE R.J. and VERNON H.: Cervical Radiculopathy: A Systematic Review on Treatment by Spinal Manipulation and Measurement with the Neck Disability Index. The Journal of the Canadian Chiropractic Association, 56: 18$28,2012$.

2- ABBED K. and COUMANS J.: Cervical Radiculopathy: Pathophysiology, Presentation, and Clinical Evaluation. Neurosurgery, 60: S28-34, 2007.

3- SAVVA C. GIAKAS G., EFSTATHIOU M. and KARAGIANNIS C.: Test Retest Reliability of Handgrip Strength Measurement Using a Hydraulic Hand Dynamometer in Patients With Cervical Radiculopathy. Journal of Manipulative and Physiological Therapeutics, 37: 206-10, 2014.

4- PEOLSSON A., LUDVIGSSON M.L., WIBAULT J., et al.: Function in Patients With Cervical Radiculopathy or Chronic WhiplashAssociated Disorders Compared With Healthy Volunteers. Journal of Manipulative and Physiological Therapeutics, 37: 211-8, 2014.

5- ARAUJO B.F., NASCIMENTO C.M. Do, BUSARELLO F. De O, et al.: Assessment of Hand Grip Strength after Neural Mobilization. Revista Brasileira de Medicina Do Esporte, 18: 242-5, 2012.

6- GABRIEL D.A., KAMEN G. and FROST G.: Neural Adaptations to Resistive Exercise. Sports Medicine, 2006

7- NEE R.J. and BUTLER D.: Management of Peripheral Neuropathic Pain: Integrating Neurobiology, Neurodynamics, and Clinical Evidence. Physical Therapy in Sport, 36-49, 2006.
8- NEE R.J., VICENZINO B., JULL G.A., et al.: Neural Tissue Management Provides Immediate Clinically Relevant Benefits Without Harmful Effects for Patients with Nerve-related Neck and Arm Pain: A Randomised Trial. Journal of Physiotherapy, 58: 23-31, 2012.

9- DABHOLKAR TEJASHREE and DABHOLKAR AJIT S.: The Effect of Nervous Tissue Mobilization on Pinch and Grip Strength. International Journal of Science and Research, 7: 751-3, 2012.

10- WALSH M.T.: Upper Limb Neural Tension Testing and Mobilization: Fact, Fiction, and a Practical Approach. Journal of Hand Therapy, 18: 241-58, 2005.

11- VILLAFAÑE J.H., SILVA G.B. and FERNANDEZCARNERO J.: Short-Term Effects of Neurodynamic Mobilization in 15 Patients with Secondary Thumb Carpometacarpal Osteoarthritis. Journal of Manipulative \& Physiological Therapeutics, 34: 449-56, 2011.

12- RAGONESE J.: A randomized trial comparing manual physical therapy to therapeutic exercises, to a combination of therapies, for the treatment of cervical radiculopathy. Orthop. Physical Therapy Practical, 21: 71-6, neurobiology, neurodynamics and clinical evidence. Physical Therapy in Sport, 7 (3): pp. 36-49, 2009.

13- NEE R.J. and BUTLER D.: Management of peripheral neuropathic pain: Integrating Page 103 of 138, 2006.

14- FIGUEIREDO I., SAMPAIO R., MANCINI M., SILVA F. and SOUZA M.: Teste de força de preensão utilizando o dinamômetro Jamar. Acta Fisiatr, 14: 104-10, 2007.

15- LEE K. and KEICKHEFER G.M.: Measuring human responses using visual analogue scales. West J. Nurs. Res., 11: 128-32, 1989.

16-McDOWELL I. and NEWELL C.A.: Guide to rating scales and questionnaires. Oxford University Press, New York, Oxford; 1987.

17- WEWERS M.E. and LOWE N.K.: A critical review of visual analogue scales in the measurement of clinical phenomena. Res. Nurs. Health, 13: 227-36, 1990.

18- JENSEN M.P., KAROLY P. and BRAVER S.: The measurement of clinical pain intensity (a comparison of six methods). Pain, 27: 117-26, 1986.

19- DUNCAN G.H., BUSHNELL M.C. and LAVIGNE G.J.: Comparison of verbal rating scales and visual analogue scales for measuring the intensity and unpleasantness of experimental pain. Pain, 37: 295-303, 1989.

20- MELZACK R. and KATZ J.: Pain measurement in persons in pain. In: P.D. Wall, R. Melzack (Eds.) Textbook of pain. ${ }^{3 \mathrm{rd}}$ ed. Churchill Livingstone, Edinburgh, 337-, 1994.

21- NORDEMAR R. and THOMER C.: Treatment of acute cervical pain: A comparative group study. Pain, 10: 93101,1981

22- Guide to Physical Therapist Practice. 2 nd ed. Phys. Ther., 81: 9-746, 2001.

23- JOGHATAEI M.T., ARAB A.M. and KHAKSAR H.: The effect of cervical traction combined with conventional therapy on grip strength on patients with cervical radiculopathy. Clin. Rehabil., 18: 879-8877, 2004 
24- TEJASHREE DABHOLKAR and AJIT DABHOLKARI: The Effect of Nervous Tissue Mobilization on Pinch \& Grip Strength, International Journal of Science and Research (IJSR), 3 (7), 2014.

25- RICHARD F. ELLIS: Post Grad Dip and Wayne A. Hing, The Journal of Manual \& Manipulative Therapy, 16 (1): $8-22,2008$.

26- COPPIETERS M.W., STAPPAERTS K.H., WOUTERS L.L. and JANSSENS K.: Journal of Orthopedic \& Sports Physiotherapy July, 33 (7): 369-78, 2003.

27- SMATI SMBYAL and SANDEEP KUMAR: Comparison Between Nerve Mobilization And Conventional Physiotherapy In Patients With Cervical Radiculopathy. Interna- tional Journal of Innovative Reasearch \& Development, 2 (8): 442-5, 2013.

28- NISHA N. RANADE and Dr. SNEHAL GHODEY: The effect of neural tissue mobilization on cylindrical grip strength in old adults. Int. J. of Allied Med. Sci. and Clin. Res., 5 (2): 414-21, 2017.

29- CLELAND J., CHILDS J., PALMER J. and EBERHART S.: Slump stretching in the management of non-radicular low back pain: A pilot clinical trial. Man. Ther., 11 (4): 279-86, 2006.

30- NAIR R., HOLLA S. and RAJADHYAKSHA S.: Effect of Neural Tissue Mobilization on Grip Strength in Patients with Cervical Radiculopathy. Journal of Society of Indian Physiotherapists., 1 (2): 47-52, 2017.

\section{تآثير التحريك العصبى الديناميكى على الآلم وقوة قبضة اليد فى مرضى إعتلال الجذور العنئية العنقية}

\footnotetext{
الخلفية: يعد إعتلال الجذود العنقية حالة مرضية تؤدى إلى العجز الحسى والحركى. هناك آدلة علمية تدعم تآتير التحريك العصبى الدينامكى فى تذفيف آعراض إعتلال الجذور العنقية.

الهدف: الهف من الدراسة هو تقييم تآثير التحريك العصبى الدينامكى على قوة قبضة اليد والآلم فى المرضى الذين يعانون من إعتلال الجذو العنقية.

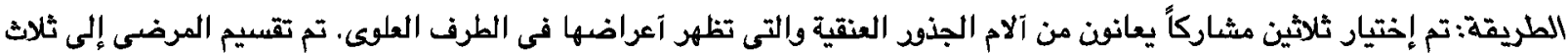

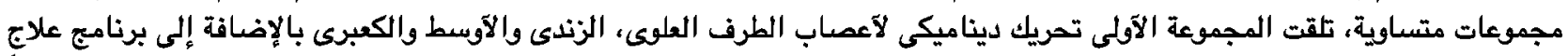

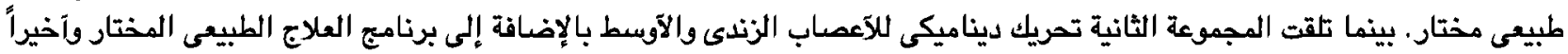

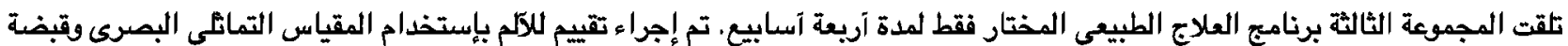
اليد بإستخدام مقياس قوة اليد المحمول قبل وبعد العلاج.

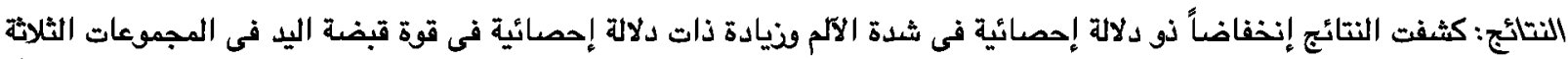

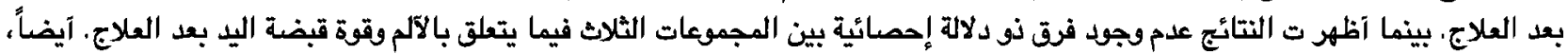

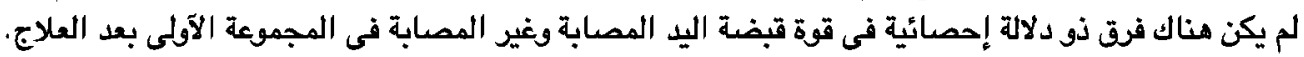

الخلاصة: يعتبر التحريك الديناميكى العصب الكمبرى بالإضافة إلى كلا من العصب الزندى والآوسط آكثر فعالية فى تصسين آعراض إعتلال الجذور العنقية المزمن.
} 